\title{
OBITUARY
}

\section{HUBERT MAITLAND TURNBULL}

H. M. Turnbull, whose death on September 29, 1955, was briefly recorded in the last issue of this journal, was for $\mathbf{4 0}$ years Director of the Bernhard Baron Institute at the London Hospital and achieved eminence as a master of morbid anatomy.

He was born on March 3, 1875, of Scottish parents, and his early years were spent in Edinburgh. His father was manager and actuary of the Scottish Widows Fund.

His education was begun at St. Ninians, Moffat, at the age of 9 and continued at Charterhouse (1888-94). Proceeding thence to Magdalen College, Oxford, he continued his classical education, but, after passing Classical Moderations, he turned to science with the plan of entering the medical profession. This idea had been suggested by his father because, as a child, Turnbull had shown a lively interest in natural history and, in particular, the study of birds. The latter remained a lifelong hobby, and he also became, in later years, a keen geologist, studying the rocks and formations of any part of the country where he happened to be on holiday. The switch-over to science at Oxford proved a great success: it let loose his pent-up abilities and native enthusiasm. After taking the Final Honour School in Physiology (1898) he attended Ritchie's class in Pathology, and, having passed in Human Anatomy with the award of the James Welch Prize, he became Demonstrator in Anatomy and Histology.

He entered the London Hospital in October, 1900, with the Price University Entrance Scholarship, and passed the Primary F.R.C.S. examination in the following month. At this time Turnbull planned to become a surgeon. But he was also keenly interested in neurology and was evidently stimulated by the teaching of Henry Head, for whom he clerked. And his thesis for the degree of D.M. (Oxford) was a neurological study which gained the approbation of Sherrington, who judged it. After qualifying in 1902 (M.R.C.S., L.R.C.P. and B.M., B.Ch.) Turnbull held the usual house appointments at the London and was then awarded the Radcliffe Travelling Fellowship of Oxford University (1904-06). This took him to the continent, first to Professor Salomonson at Copenhagen, where he also studied under Dr. Georges Dreyer, and later to Dresden. Work in morbid anatomy at Dresden under the inspiring guidance of ProfesserGeorg Schmorl revolutionized Turnbull's ideas about ${ }^{\circ}$ his future. Schmorl was noted for his work on bone $\overrightarrow{\vec{c}}$ pathology, and Tuinbull had gone to Dresden primarilyo to become versed in this as a prelude to entering orthopaedic surgery. In the early years of this century morbid? anatomy was regarded, at least in this country, as $a_{-}^{\circ}$ subject which had nothing more to offer : it had been sucked dry by Virchow and his school, and bacteriology was in the ascendant. But at Dresden the lively teaching and work of Schmorl gave the lie to all this ; so much so that Turnbull resolved to given his future to morbid anatomy and to redeem its status in England.

His appointment as Director to the Institute of Pathology at the $\overrightarrow{0}$ London Hospital in 1906 began as period during which he exerted an immense influence upon the stan-o dard of work performed not only in the hospital but in other centreso far and near. The factors contributing to this were various. First $\stackrel{\mathbb{Q}}{\mathbb{Q}}$ and most important, was the character of the man. To his pupilso his most salient feature was his un-? compromising devotion to truth and accuracy. This particular. quality, indeed, ran like a goldeno thread through every aspect of his work as well as his relationships 3 with colleagues, pupils, and friends Translated into action as director, if involved a thorough and punctilious technique, the accurate recording of weights and measurements, and the careful; maintenance of alp records as well as the material upon

[J. Russell \& Sons, London which diagnoses were based. In diagnosis Turnbull everos method, and few things annoyed him more than the arrival through the post of a single slide, stained with haematoxylin and eosin, for his opinion in a difficult case. But, having secured the paraffin block, his eventua은 report, which would include observations made by using $\bar{D}$ a variety of techniques, was an education to the recipient?

The numerous voluntary workers who came to study at the Institute, from 1908 onwards, carried these pre-웅 cepts to other parts of this island and to many countries abroad. Likewise pathologists who received their early training from Turnbull migrated to take up important positions elsewhere, both academic and othetwise. AlK of these served as focal points of influence and cumula- 
tively helped to restore morbid anatomy to its rightful position as a basic medical science. The early years of Turnbull's directorship were not easy : he had to fight for what he knew to be essential against apathy and the die-hards intolerant of change. His ultimate achievement was recognized beyond the confines of academic pathology, and in 1929 he received the F.R.C.P., followed by the F.R.S. in 1939 and the D.Sc. honoris causa from Oxford in 1945. The University of London conferred on him the title of Professor in 1919.

As a teacher Turnbull gained a following because his discourse was based upon personal observations ; it was truthful, accurate, and often in advance of the current textbooks. If obliged to quote the observations of others, he always gave his authority. He inspired others not by eloquence but by his character and work. Considerable though the volume of his work proved, it was most regrettably curtailed and interrupted by illness, particularly migraine which afflicted him from his schooldays onwards. This complaint made him loth to attend meetings or to give public lectures : hence he was not as widely known personally as would otherwise have been the case. To those who sought him out he was unfailingly helpful and generous.

In person he was tall and thin : his face in repose was austere and thoughtful. But in conversation he was animated and humorous, with a ready stock of jokes and anecdotes. In his relationships with others he was thoughtful, sensitive, and just, but notably shy and reserved. In the face of others' troubles he was profoundly altruistic; his own setbacks were met with superb moral and physical courage.

Much of Turnbull's work was incorporated in the publications of his pupils and colleagues, and to these he gave a large proportion of his time. He displayed little urge to publish under his own name, although his passion for research was undiminished to the end. His rigorous self-criticism permitted little of this research to reach editorial hands. And his hope of completing much of his work, especially in bone pathology, during the years of retirement was defeated by ill-health. He will, however, be remembered by the studies on metabolic bone-disease, done with Donald Hunter, by his early discovery of post-vaccinal encephalomyelitis, and by his classical study of arterial disease (Quart. J. Med., 1915). We may hazard that he will be remembered even longer as the man of vision who set a high standard for morbid anatomy in this country at the start of the century and educated others up to it.

He married, in 1916, Catherine Nairne Arnold Baker, who died in 1933 : they are survived by one daughter and three sons.

D. S. R.

\section{BOOK REVIEWS}

Cancer : Race and Geography. First edition. By Paul E. Steiner. (Pp. xiv $+364 ; 50$ tables, 73 figures. 38s. 6d.) London : Baill:ère, Tindall \& Cox. 1954.

This is a timely and commendable book by which the author, justifiably, hopes to stimulate research and new ideas on aetiology, and to concentrate thought on the control of cancer through prevention. Despite its great potentialities, the ethnic and geographic study of malignant disease has been relatively neglected in cancer research. Here, by analysing his own material, drawing together the available literature and pointing out its deficiencies, Professor Steiner indicates paths along which such research may be pursued. He admits the quantitative inadequacy of some of the material on which his study is based, and anticipates the displeasure of some biostatisticians, but he feels that the aetiology of cancer is too pressing a problem to postpone till perfect data are available.

Necropsies at the Los Angeles County Hospital between the years 1918 and 1947 provided the material for statistical analysis. Of the total of 35,293 , there were 6,072 cancer cases. These are classified according to racial groups: Caucasoids 5,120, Mexicans 590, Negroids 284, and Mongoloids 78 (composed of Japanese 58, Philippinos 11, Chinese 9), tumour site (carcinomas), or type, sex, and age. The varieties of tumours are listed under 54 headings, but, because most of the groups are not large enough, only the 20 commonest $(91.2 \%$ of the total) are dealt with in detail, a chapter being devoted to each. All the information is thoroughly analysed, there being no fewer than 123 tables and figures : summaries are profuse and there is a good, full index.

So far as published figures allow, comparison is made between the racial groups in their native and other countries (sedentes versus migrants) to determine whether differences in frequency of some forms of cancer are due to environmental or hereditary factors. Racial biological differences other than frequency are also reviewed in each chapter. From this information an attempt is made to arrive at aetiological implications.

The author concludes that, in general, racial differences in cancer are due to environmental rather than hereditary factors, that geographical differences tend to be environmental rather than racial, and that hereditary differences tend to be explained by cultural rather than genetic factors.

\section{J. W. WhitTick.}

The Skin : A Clinicopathologic Treatise. By Arthur C. Allen. (Pp. $x v+1,048 ; 495$ full-page illustrations. $£ 9$ 7s. 6d.) London: Henry Kimpton. 1954.

The publication of this book has been eagerly awaited by those who knew of the project, as the author has had extensive experience in histopathology of the skin, both in the Armed Forces Institute of Pathology and at the Memorial Cancer Centre. The collaboration of Sophie Spitz, wife of the author, in work on naevi and malignant melanomas has resulted in Allen's recognition as one of the chief present-day protagonists in the epidermalneurogenetic controversy regarding the origin of these 